\title{
Bloqueio do Plexo Braquial por Via Infraclavicular: Abordagem Antero-Posterior *
}

\section{Infraclavicular Brachial Plexus Block: Antero Posterior Approach}

\author{
Luiz Eduardo Imbelloni, TSA ${ }^{1}$, Lúcia Beato ${ }^{2}$, M. A. Gouveia, TSA ${ }^{3}$
}

\author{
RESUMO \\ Imbelloni LE, Beato L, Gouveia MA - Bloqueio do Plexo Braquial \\ por Via Infraclavicular: Abordagem Ântero-Posterior
}

Justificativa e Objetivos - O bloqueio do plexo braquial é a técnica preferida pelos anestesiologistas para cirurgias nos membros superiores. Embora o acesso infraclavicular seja menos utilizado, ele pode oferecer algumas vantagens. O objetivo deste estudo prospectivo é mostrar os resultados observados em 50 pacientes submetidos a bloqueio do plexo braquial pela via infraclavicular, usando estimulador de nervo periférico e abordagem ântero-posterior.

Método - Cinqüenta pacientes, com idades entre 17 e 87 anos, estado físico ASA I e II, escalados para cirurgias ortopédicas da extremidade superior foram anestesiados com bloqueio do plexo braquial pela via infraclavicular. Todos os bloqueios foram realizados com estimulador de nervo periférico, a partir de $1 \mathrm{~mA}$. Quando se obtinha uma adequada contração muscular na mão, no antebraço ou músculos do braço, a amperagem era diminuída até desaparecimento da resposta. Se a resposta desaparecesse com estímulo superior a 0,6 $\mathrm{mA}$, a agulha poderia ser movimentada a procura de melhor resposta. Se a resposta não desaparecesse com estímulo menor que 0,5 mA, injetavam-se $50 \mathrm{ml}$ de lidocaína a 1,6\% com epinefrina 1:200.000. Foram avaliados o tempo de latência, duração da cirurgia, tolerância ao uso do torniquete, duração dos bloqueios sensitivo e motor, complicações e efeitos adversos.

Resultados - O bloqueio foi efetivo em $94 \%$ dos pacientes, o tempo médio da latência foi de $8,78 \mathrm{~min}$, a duração média da cirurgia foi de 65,52 min e a tolerância ao torniquete foi observada em todos os pacientes. A média de duração do bloqueio sensitivo foi de 195,56 min e do bloqueio motor de 198,86 min. Ocorreu uma punção vascular. Não foram observados sinais e sintomas clínicos de toxicidade do anestésico local ou do vasoconstritor. Nenhum paciente apresentou efeitos adversos do bloqueio.

Conclusões - O bloqueio infraclavicular do plexo braquial proporciona uma anestesia efetiva para cirurgias dos membros superiores. Acreditamos que a técnica utilizando o estimulador

\footnotetext{
* Recebido da (Received from) Clínica São Bernardo, Casa de Saúde

Santa Maria e Hospital Samaritano, Rio de Janeiro, RJ

1 Anestesiologista da Clínica São Bernardo e Casa de Saúde Santa Maria. Rio de Janeiro, RJ

2. $M E_{2}$ do CET/SBA do Hospital Pedro Ernesto - Rio de Janeiro, RJ

3. Anestesiologista da Clínica Santa Bárbara e Hospital Samaritano, Rio de Janeiro, RJ
}

Apresentado (Submitted) em 31 de julho de 2000

Aceito (Accepted) para publicação em 25 de outubro de 2000

Correspondência para (Mail to):

Dr. Luiz Eduardo Imbelloni

Av. Epitácio Pessoa, 2356/203 - Lagoa

22471-000 Rio de Janeiro, RJ

E-mail: imbelloni@openlink.com.br

(C) Sociedade Brasileira de Anestesiologia, 2001 de nervos periféricos proporciona um alto índice de sucesso e demonstrou ser segura. Não foi observado nenhum caso de pneumotórax ou qualquer outro tipo de complicação. A solução do anestésico utilizada proporcionou uma anestesia adequada e segura.

UNITERMOS - ANESTÉSICOS, Local: lidocaína; CIRURGIA, Ortopédica; TÉCNICAS ANESTÉSICAS, Regional: plexo braquial

\section{SUMMARY}

Imbelloni LE, Beato L, Gouveia MA - Infraclavicular Brachial Plexus Block: Antero Posterior Approach

Background and Objectives - Brachial plexus block is the preferred anesthetic technique for upper limb surgery. Although less commonly used, the infraclavicular brachial block may have some advantages. In this study we present the results of 50 patients submitted to infraclavicular plexus block by the antero posterior approach with the aid of a nerve stimulator.

Methods - Fifty patients, aged 17 to 87 years, physical status ASA I and II, scheduled for upper limb orthopedic surgery, were submitted to brachial plexus block by the infraclavicular approach. All blocks were performed with the help of a peripheral nerve stimulator starting at $1 \mathrm{~mA}$. When an adequate hand, forearm or arm muscle contraction was obtained the current was decreased until the disappearance of the response. If there was no response with a stimulus above $0.6 \mathrm{~mA}$, the needle was relocated in search for a better response. If response persisted with a stimulus below $0.5 \mathrm{~mA}, 50 \mathrm{ml}$ of $1.6 \%$ lidocaine with epinephrine 1:200,000 were injected. The following parameters were evaluated: block onset time, surgery duration, tourniquet tolerance, sensory and motor block duration, complications and side effects.

Results - Blockade was effective in $94 \%$ of patients; mean onset time was $8.78 \mathrm{~min}$, surgical mean duration was $65.52 \mathrm{~min}$, tourniquet tolerance was $100 \%$, mean sensory block duration was 195.56 min and mean motor block duration was 198.86 $\min$. There has been one vascular puncture. There were no clinical signs or symptoms of toxic effects of local anesthetics and vasoconstrictors. No patient showed blockade side effects.

Conclusions - Infraclavicular plexus block provides an effective anesthesia for upper limb surgery. The use of a nerve stimulator helps the technique to be both highly successful and safe: no pneumothorax or any other major complication were observed. The local anesthetic solution used provided an adequate and safe anesthesia.

KEY WORDS - ANESTETHICS, Local: lidocaine; ANESTHETIC TECHNIQUES, Regional: brachial plexus; SURGERY, Orthopedic

\section{INTRODUÇÃO}

/árias formas de atingir o plexo braquial têm sido descritas, incluindo o uso de parestesia, punção transarterial, perda da resistência na bainha nervosa e neuroestimulação. As técnicas incluem a via axilar ${ }^{1,2}$ ou acima da clavícula, 
pelo bloqueio supraclavicular ${ }^{3-5}$ ou bloqueio interescalênico ${ }^{5-7}$. O local de acesso ao plexo braquial depende da região a ser operada. $\mathrm{O}$ acesso axilar é freqüentemente utilizado para proporcionar anestesia para cirurgias do antebraço e mão, e os acessos supra-claviculares ou interescalênicos são indicados para cirurgias acima do cotovelo ou do ombro. Existem argumentos contra e a favor em cada método e nenhum é geralmente aceito como claramente superior aos demais ${ }^{2,8}$. Aidentificação do plexo braquial através da parestesia é provavelmente a técnica mais comumente utilizada. A parestesia é associada a aumento de neuropatia pós-operatória, apesar das precauções em se evitar dano nervoso secundário ao trauma da agulha ou da injeção intraneural ${ }^{9}$. A técnica de transfixação arterial pode resultar no aumento do risco de complicações vasculares, incluindo vasoespasmo, injeção intravascular, formação de hematoma e completa obliteração da artéria axilar ${ }^{2}$. A utilização de estimulador de nervo periférico permite um procedimento delicado no sentido de posicionar a ponta da agulha junto ao nervo, além de ser bem tolerado pelo paciente porque não é necessário pesquisar parestesia $^{10}$.

A técnica de acesso ao plexo braquial pela via infraclavicular foi descrita no início do século 20 e revista em $1973^{11}$, mostrando que produz um extenso bloqueio do membro superior, sem o risco de punção pleural. Recentemente algumas publicações têm sido realizadas com este acesso, produzindo uma anestesia segura, com mínimas complicações e poucos efeitos colaterais ${ }^{12-14}$.

O objetivo deste estudo é apresentar uma variação do acesso ao plexo braquial pela via infraclavicular, assim como os resultados obtidos com lidocaína em cirurgias ortopédicas dos membros superiores.

\section{MÉTODO}

Após aprovação da Diretoria de Publicação e Divulgação da Clínica, participaram deste estudo prospectivo 50 pacientes, com idades entre 17 e 87 anos, estado físico ASA I e II, submetidos a cirurgias ortopédicas de membros superiores. Todos os pacientes receberam explicações detalhadas sobre a técnica, após o que deram seu consentimento.

Nenhum paciente recebeu medicação pré-anestésica no quarto. Após venóclise com cateter $18 \mathrm{G}$ ou $20 \mathrm{G}$ foi iniciada infusão lenta de solução de Ringer com lactato. Amonitorização na sala de operações foi realizada pelo ECG contínuo na posição CM5, pressão arterial por método não invasivo e oximetria de pulso. Os pacientes só receberam sedação com midazolam e meperidina, após instalação do bloqueio e início da cirurgia.

\section{Técnica}

Os pacientes foram colocados em decúbito dorsal com o braço a ser operado confortavelmente estendido ao longo do corpo (exceto quando impossibilitado), com a cabeça voltada para o lado oposto e o ombro abaixado como se a mão tentasse tocar joelho (quando possível). Didaticamente dese- nha-se o contorno da clavícula e do processo coracóide (Figuras 1 e 2). Na fossa infraclavicular, encontrada na maioria dos pacientes magros, marca-se um ponto a $1,5 \mathrm{~cm}$ abaixo do ponto de união entre o terço lateral e os dois terços mediais da clavícula. Este ponto deve ficar entre 1,5 a $2 \mathrm{~cm}$ medial ao processo coracóide. Depois de fazer um botão dérmico no ponto marcado, uma agulha de $50 \mathrm{~mm}$, eletricamente isolada e conectada a um estimulador (Stimulplex ${ }^{\circledR}$, B. Braun Melsungen $A G$, agulha $22 \mathrm{G}$ com $0,70 \times 50 \mathrm{~mm}$ ), regulada para liberar uma corrente pulsátil quadrada de $1 \mathrm{~mA}$, com freqüência de $1 \mathrm{~Hz}$, é inserida em sentido ântero-posterior até se obter contração de um dos músculos do braço ou do antebraço ou flexão (n. medial) ou extensão (n. radial) da mão como resposta a estímulos do plexo braquial. De um modo geral, a penetração da agulha pode variar de $2,5 \mathrm{a} 4 \mathrm{~cm}$, de acordo com a compleição física do paciente. Quando se obteve boa resposta contrátil, a corrente do estimulador foi redimensionada para valores mais baixos. Se a resposta não desaparecesse aos estímulos abaixo de $0,5 \mathrm{~mA}$, certamente a ponta romba da agulha estaria bem próxima do plexo braquial e a injeção da solução era realizada. Após início da contração e aspiração negativa para sangue, foram injetados $50 \mathrm{ml}$ de lidocaína a 1,6\%, com epinefrina 1:200.000, preparada na hora.

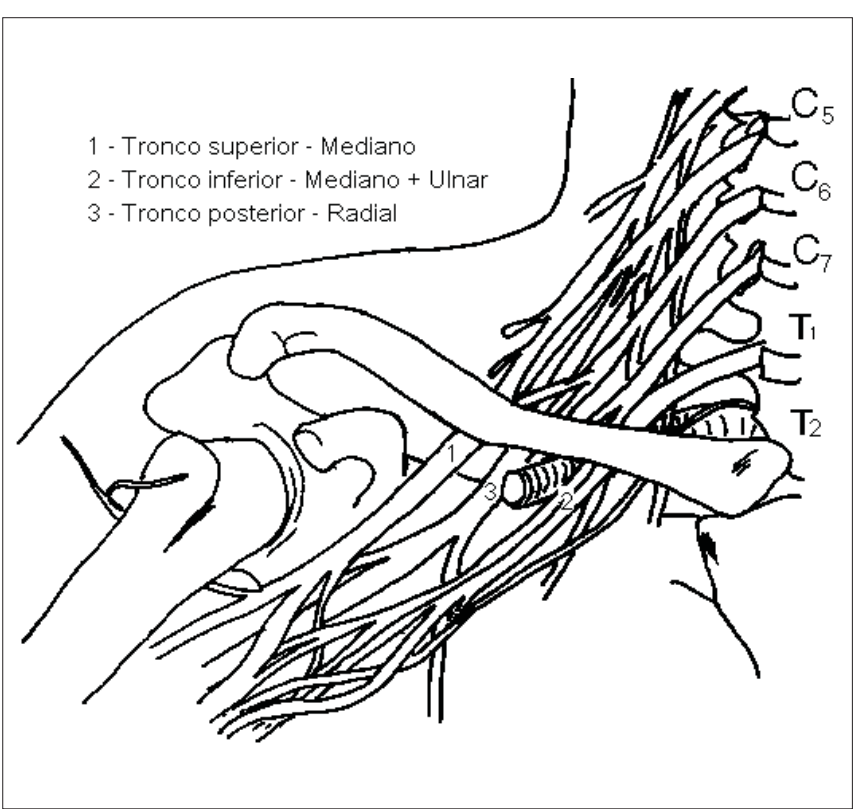

Figura 1 - Local de Punção

A analgesia foi avaliada pelo teste doloroso com pinça cirúrgica para determinar a extensão do bloqueio sensitivo apenas para os nervos radial, mediano e ulnar. Foram avaliados os seguintes parâmetros: 1) latência da anestesia, tempo após injeção do anestésico e perda da sensibilidade nos três nervos; 2) duração do procedimento cirúrgico, tempo entre injeção do anestésico e término da cirurgia; 3) duração do bloqueio sensitivo, medido pelo tempo entre a injeção do 


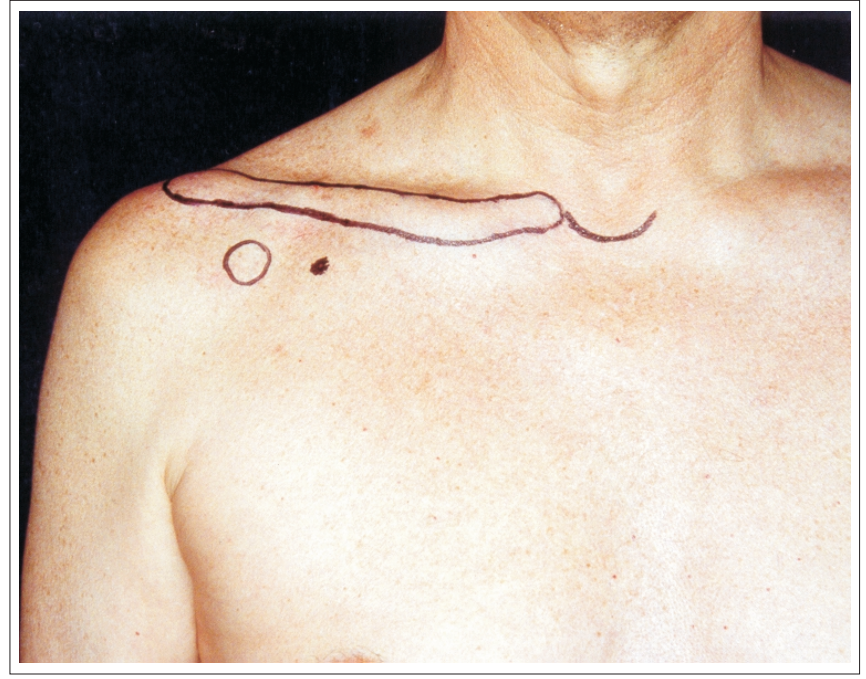

Figura 2 - Local de Punção

anestésico e a completa recuperação da sensibilidade; 4) duração do bloqueio motor; tempo entre a injeção do anestésico e a completa recuperação dos movimentos do membro; 5) percepção do garrote; e, 6) complicações e efeitos colaterais. Em caso de falha parcial ou completa, o protocolo permitia complementação por injeção interescalênica da metade da dose preconizada. Em alguns pacientes foram injetados $20 \mathrm{ml}$ do contraste Omnipaque com $300 \mathrm{mg} \cdot \mathrm{ml}^{-1}$ associado ao anestésico, para estudo da dispersão do volume injetado com 1 minuto e 60 minutos (Figuras 3 e 4).

No final da cirurgia, o paciente foi transferido para o quarto e se se queixasse de dor, uma solução contendo $30 \mathrm{mg}$ de meperidina e $300 \mathrm{mg}$ de dipirona era administrada por via venosa. Os pacientes foram acompanhados durante 48 horas para verificação de complicações no local do bloqueio e satisfação com a técnica.

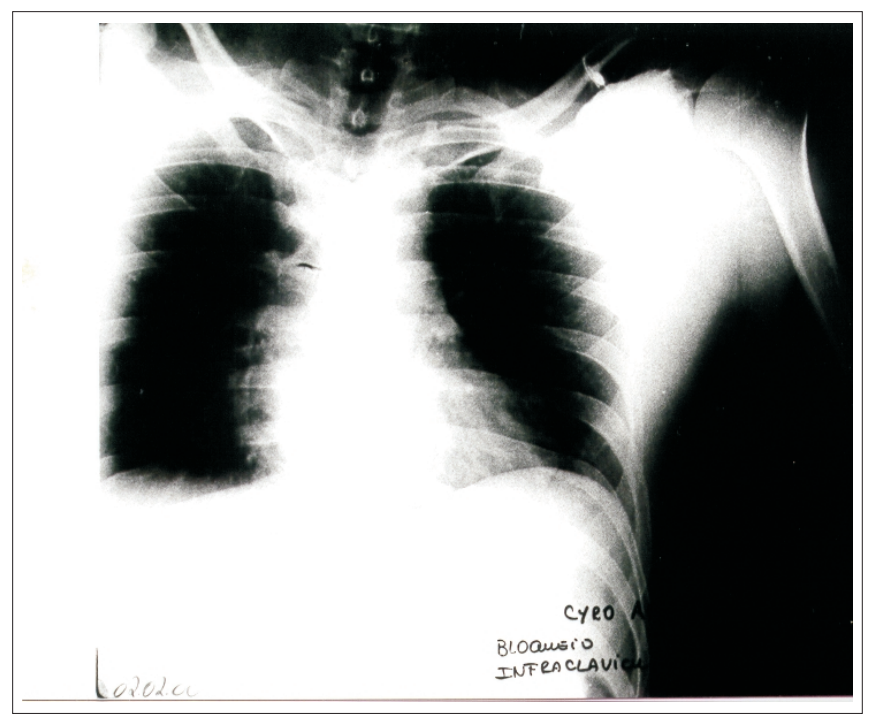

Figura 3 - Injeção de Contraste juntamente com Anestésico Local

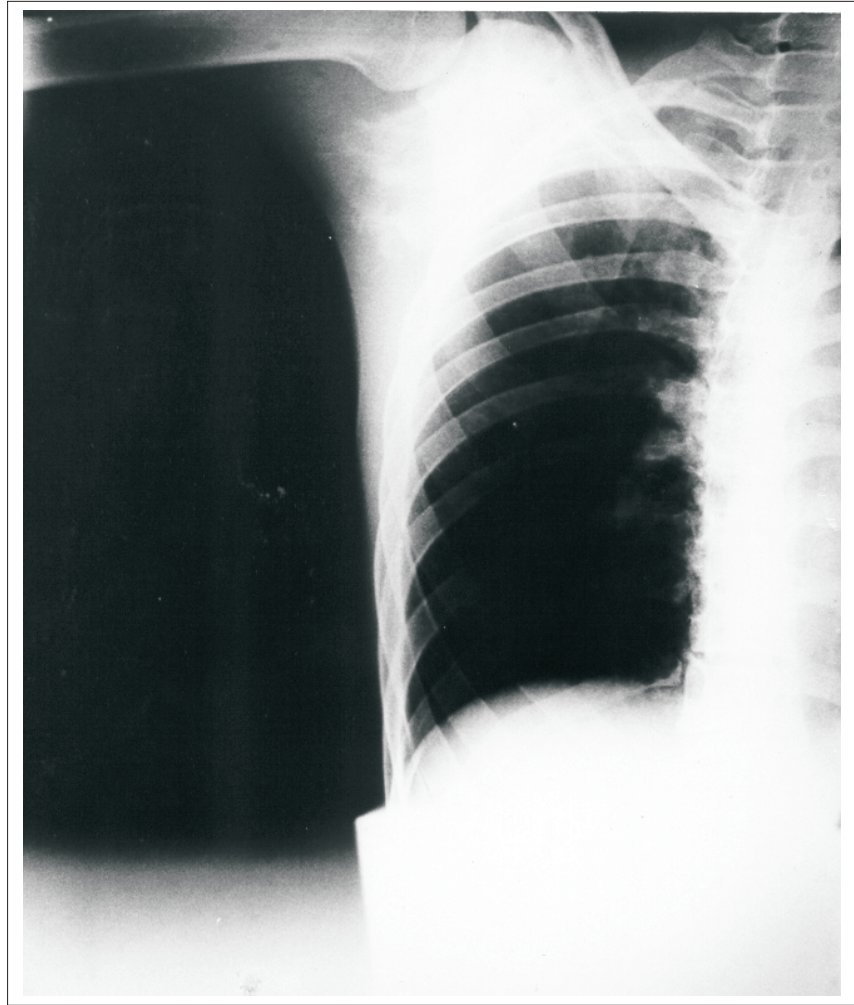

Figura 4 - Injeção de Contraste 60 Minutos Após

Os resultados foram avaliados pela análise descritiva das variáveis estudadas e, quando possível, pela média e desvio padrão.

\section{RESULTADOS}

Os dados demográficos estão apresentados na tabela I. A analgesia foi adequada em 47 pacientes (94\%), parcial em dois pacientes $(4 \%)$ e com falha em um paciente $(2 \%)$. O nervo ulnar foi bloqueado em todos os pacientes, ocorrendo faIha no radial em um paciente e no mediano em dois pacientes. A tolerância ao garrote foi de $100 \%$ nos pacientes em que foi utilizado (46 pacientes). A satisfação com a técnica ocorreu em 48 pacientes ( $96 \%$ ) e os dois pacientes que receberam uma segunda punção para realização do bloqueio interescalênico não ficaram satisfeitos com a técnica. Ocorreu punção vascular em um paciente antes da injeção da solução anestésica. Aagulha foi reposicionada e o bloqueio realizado sem problemas.

\section{Tabela I - Dados Demográficos}

\begin{tabular}{lc}
\hline Idade $(\mathrm{anos})^{*}$ & $41,40 \pm 18,02$ \\
Peso $(\mathrm{kg})^{*}$ & $69,98 \pm 12,84$ \\
Altura $(\mathrm{cm})^{*}$ & $167,98 \pm 09,29$ \\
Sexo & \\
$\quad$ Masculino & 28 \\
$\quad$ Feminino & 22 \\
\hline
\end{tabular}

* Valores expressos pela Média \pm DP 
Em sete pacientes (14\%) a cirurgia foi realizada no braço, em quatro dos quais não foi usado o garrote.

O tempo para instalação da analgesia foi de 8,78 min e o tempo cirúrgico de $65,52 \mathrm{~min}$. O retorno da sensibilidade foi de $195 \mathrm{~min}$ e do bloqueio motor de $198 \mathrm{~min}$ (Tabela II).

Tabela II - Efeitos do Bloqueio

\begin{tabular}{lc}
\hline $\begin{array}{l}\text { Nervos bloqueados } \\
\text { Radial }\end{array}$ & $48(96 \%)$ \\
Mediano & $48(96 \%)$ \\
Ulnar & $50(100 \%)$ \\
Analgesia & \\
$\quad$ Adequada & $47(94 \%)$ \\
Parcial & $02(04 \%)$ \\
Falha & $01(02 \%)$ \\
Tolerância ao garrote & \\
Uso em 44 pacientes & $44(100 \%)$ \\
02 pacientes + interescalênico & $02(100 \%)$ \\
04 pacientes sem garrote & $8,78 \pm 3,22\left(^{*}\right)$ \\
Tempo de latência (min) & $195,56 \pm 37,23\left(^{*}\right)$ \\
Tempo de analgesia (min) & $198,86 \pm 37,56\left(^{*}\right)$ \\
Tempo de bloqueio motor (min) & $48(96 \%)$ \\
Satisfação com a técnica &
\end{tabular}

$\left(^{*}\right)$ Valores expressos pela Média \pm DP

O estudo contrastado do bloqueio, realizado em dois pacientes, demonstrou que a mistura se encontrava dentro do espaço infraclavicular (Figura 2) e que 60 minutos após difundia para a região axilar (Figura 3 ).

Nenhum paciente apresentou sinais clínicos (dispnéia e cianose) de paralisia diafragmática unilateral secundária ao bloqueio do nervo frênico. Não foi observada nenhuma complicação no local da punção.

\section{DISCUSSÃO}

Atécnica infraclavicular de abordagem ao plexo braquial proporciona uma consistente, reproduzível e efetiva anestesia dos membros superiores. Acreditamos que a maior razão do sucesso desta técnica é a colocação do anestésico local na passagem dos ramos lateral, posterior e inferior do plexo braquial por adequada localização do plexo pela neuroestimulação. Aefetividade do bloqueio infraclavicular (94\%) é comparável aos resultados dos acessos por via axilar, supraclavicular e interescalênico ${ }^{1,15-17}$.

De um modo geral, a via de escolha para acesso ao plexo braquial está na dependência do local a ser operado. Abordagem da via axilar é apropriada para intervenções na mão, enquanto que para lesões mais proximais pode-se usar as vias infraclavicular, supraclavicular e interescalênica. A anestesia na parte proximal do membro superior (braço) se mostrou efetiva pela tolerância ao uso do garrote, em todos os pacientes, assim como em $14 \%$ dos pacientes que foram submeti- dos a cirurgias no braço. Isto implica também em bloqueio dos nervos axilar e parte do intercostobraquial.

A técnica infraclavicular foi descrita por Labat em 1930, com uma abordagem no sentido medial, posterior e cefálica ${ }^{18}$, a partir de um ponto infraclavicular bem na metade do comprimento da clavícula, tendo como ponto alvo o tubérculo de Chassaignac. Em 1973 foi reavaliada por Raj, que empregou uma abordagem inversa, no sentido de proteger o paciente do risco potencial de um pneumotórax ${ }^{11}$. Outros autores propõem uma abordagem no sentido da borda superior da segunda costela a partir de um ponto infraclavicular logo abaixo da união do terço lateral com os dois terços mediais, o que nos parece também favorecer a ocorrência de pneumotórax ${ }^{12}$. Nossa opção por uma abordagem ântero-posterior insere a agulha paralelamente ao gradil costal e também reduz a possibilidade de pneumotórax. Além disso, facilita a abordagem por reduzir a distância entre o ponto de entrada da aguIha e o plexo braquial (Figura 4).

Sempre que se realiza o bloqueio do plexo braquial há uma preocupação com o volume a ser injetado. A possível relação entre o volume de anestésico injetado e a extensão da analgesia foi primeiramente descrita em $1961^{19}$. Volumes entre 40 e $55 \mathrm{ml}$ de anestésico cursam com maior incidência de sucesso do bloqueio do plexo braquial, independentemente da via de abordagem escolhida ${ }^{15}$. Na abordagem infraclavicular, o uso de $50 \mathrm{ml}$ de lidocaína a 1,6\% com epinefrina $1: 200.000$ foi responsável pelo sucesso do bloqueio em $94 \%$ dos pacientes. Adistribuição da analgesia depende em parte do volume empregado. Soluções diluídas e maiores volumes favorecem a expansão do bloqueio tanto no sentido cranial como no sentido distal, permitindo inclusive procedimentos sobre o ombro.

O primeiro uso do estimulador de nervos para bloqueio nervoso ocorreu em $1912^{20}$. Por se tratar de um equipamento grotesco e rudimentar, seu uso foi logo abandonado. Posteriormente foi reintroduzido por Greenblatt e Denson ${ }^{21}$. Dentre uma variedade de fabricantes atuais, optamos pelo que foi considerado de melhor qualidade por sua acurácia ${ }^{22}$. O estimulador deve fornecer uma onda quadrada, de amperagem graduável ao centésimo, e que estimule preferencialmente as fibras motoras, oferecendo como resposta de sua localização a contração muscular, antes que se obtenha como resposta uma sensação de dor.

Inserida a agulha e obtida a resposta muscular, a amperagem de saída do estimulador foi diminuída para valores próximos de 0,5 mA (mais ou menos). A presença de apenas uma débil resposta muscular indicava o correto posicionamento da agulha. Após aspiração negativa, o volume da solução calculado para o paciente era então injetado com seringa de $10 \mathrm{ml}$, lentamente, enquanto se observava por aspiração intermitente a possibilidade de localização vascular da agulha e os sinais clínicos de absorção. A opção por agulha eletricamente isolada é importante para que a corrente emitida pelo estimulador tenha sua saída dirigida para a ponta da agulha, permitindo que se trabalhe com menores amperagens ${ }^{23,24}$ e se obtenha resposta fidedigna de localização próxima do nervo, o que pode não ocorrer quando se trabalha 
com agulha convencional, que, além de exigir maior amperagem, ainda pode confundir-nos quanto a sua localização em função de contrações musculares provocadas por corrente liberada ao longo da agulha para os músculos que atravessa. O uso de estimulador para localização do plexo braquial (ou qualquer outro complexo nervoso) oferece a vantagem de provocar uma contração muscular quando se aproxima de um nervo (resposta à estimulação elétrica) sem necessidade de um estímulo mecânico doloroso (parestesia), que potencialmente pode provocar neurite, ainda que pouco freqüente. Ainformação é de confiança e o índice de resultados positivos chega a $97 \%{ }^{17}$.

Diferente de outros autores ${ }^{17}$, realizamos o bloqueio com auxílio do estimulador de nervos, sem nenhuma medicação sedativa ou analgésica, e os pacientes permaneciam acordados até que ocorresse bloqueio completo dos três nervos. Este deve ter sido o motivo da insatisfação com a técnica nos dois pacientes que necessitaram de complementação com bloqueio interescalênico por falha parcial ou completa do bloqueio infraclavicular.

Alguns autores advogam o uso de múltiplas injeções pela presença de vários compartimentos na bainha neurovascu$\operatorname{lar}^{25}$. A injeção do anestésico local pela via infraclavicular foi realizada num ponto injeção único e ficou demonstrado que com a alta efetividade do bloqueio, injeções múltiplas são desnecessárias nesta abordagem.

A complicação mais importante dos acessos supraclavicular e infraclavicular é a ocorrência de pneumotórax, com relatos de 0,5 a $6 \%{ }^{26}$. Embora potencialmente perigoso, sua incidência é extremamente baixa se a técnica for realizada dentro de rigoroso protocolo. A ausência de pneumotórax em mais de 700 casos $^{27}$ demonstra que, tendo a segunda costela como guia, a pleura fica a mais de $5 \mathrm{~cm}$ de profundidade em relação ao ponto de inserção da agulha. Nesta pequena série de pacientes não foi observado nenhum caso de pneumotórax. Aausência de reações tóxicas durante e após a injeçãoe a ausência de depressão respiratória demonstram a segurança desta abordagem do plexo braquial. Da mesma forma que, ao utilizarmos o mesmo volume e a mesma concentração de lidocaína em bloqueio do plexo braquial via axilar ${ }^{1}$, não observamos nenhuma reação tóxica ao anestésico.

No acesso ao plexo braquial pela via interescalênica, pode ocorrer paralisia do nervo frênico e do diafragma em 100\% dos casos se um volume de $40-50 \mathrm{ml}$ for injetado ${ }^{28,29}$. A diminuição do volume e uma pressão digital aplicada próxima à área de injeção não previnem esta complicação ${ }^{30}$. Já no acesso infraclavicular, fica impossível ocorrerem paralisias do nervo frênico e do diafragma e não ocorrem alterações na função respiratória ${ }^{13}$. Nesta série não foi observado nenhum caso de bloqueio do nervo frênico. Todos os pacientes receberam oxigênio e mantiveram ventilação espontânea, sem queixa, com ou sem sedação. Embora a artéria axilar, juntamente com suas veias, faça parte do feixe vásculo-nervoso, não tivemos nenhum caso de hematoma ou injeção intravascular. Nenhum paciente apresentou sinais ou sintomas de intoxicação por anestésico local. Nenhum paciente apresentou síndrome de Claude Bernard Horner.
Concluindo, o alto grau de sucesso e a ausência de complicações quando se utiliza o estimulador de nervo para o acesso infraclavicular ao plexo braquial, demonstra que é uma técnica segura, efetiva e de fácil realização.

\section{Infraclavicular Brachial Plexus Block: Antero Posterior Approach}

Luiz Eduardo Imbelloni, M.D., Lúcia Beato, M.D., Marildo Assunção Gouveia, M.D

\section{INTRODUCTION}

Several brachial plexus approaches have been described, including the use of paresthesia, transarterial puncture, loss of resistance of nervous sheath and neurostimulation. Techniques include the axillary or above the clavicle approaches ${ }^{1,2}$ like the supraclavicular ${ }^{3-5}$ and interscalenic block ${ }^{5-7}$. Brachial plexus access site depends on the region to be operated. The axillary access is often used for providing anesthesia for forearm and hand while supraclavicular or interscalenic approaches are indicated for surgeries above the elbow or shoulder. There are arguments both in favor and against each method and none is generally accepted as clearly better than the others ${ }^{2,8}$. Brachial plexus identification by paresthesia is probably the most frequent technique. Paresthesia is associated to an increase in postoperative neuropathies, in spite of all precautions to avoid nervous injury secondary to needle or intraneural injection trauma ${ }^{9}$. Arterial transfixation may result in an increasing risk of vascular complications, including vasospasm, intravascular injection, hematomas and complete axillary artery occlusion ${ }^{2}$. The use of a peripheral nerve stimulator allows for a delicate procedure of positioning the needle close to the nerve, in addition to be well tolerated because there is no need to look for paresthesia ${ }^{10}$.

The infraclavicular plexus block technique was described in the early $20^{\text {th }}$ Century and was reviewed in $1973^{11}$. It has been shown that it produces an extensive upper limb block with no risk of pleural puncture. Recently, some publications have reported the use of this technique to produce a safe anesthesia with minimal complications and few side effects ${ }^{12-14}$.

This study aimed at presenting an infraclavicular plexus block variation and the results obtained with lidocaine in upper limb orthopedic surgeries.

\section{METHODS}

After the Clinic's Publication and Disclosure Department approval, participated in this prospective study 50 patients, aged 17 to 87 years, physical status ASA I and II submitted to upper limb orthopedic surgeries. All patients received detailed information about the procedure and gave their consent. 
No patient was premedicated in the room. After venoclysis with an $18 \mathrm{G}$ or $20 \mathrm{G}$ catheter, a slow lactated Ringer's infusion was started. Monitoring in the operating room consisted of continuous ECG in CM5, non-invasive blood pressure and pulse oximetry. Patients were only sedated with midazolam and meperidine after blockade installation and beginning of the surgery.

\section{Technique}

Patients were placed in the supine position with the arm to be operated comfortably extended along the body (except when impossible), with the head turned to the opposite side and the shoulder down as if the hand was trying to reach the knee (when possible). For didactic purposes the contour of the clavicle and of the coracoid process were drawn (Figures 1 and 2 ). In the infraclavicular fossa, found in most slim patients, a point $1.5 \mathrm{~cm}$ below the union point between the lateral third and the two medial thirds of the clavicle was marked. This point must be 1.5 to $2 \mathrm{~cm}$ medial to the corachoid process. After local anesthesia in the marked point, a $50 \mathrm{~mm}$ electrically insulated needle connected to a stimulator (Stimulpex ${ }^{\circledR}, \mathrm{B}$. Braun Melsungen AG, $0.70 \times 50 \mathrm{~mm} 22 \mathrm{G}$ needle) set to deliver a square current $1 \mathrm{~mA}-1 \mathrm{~Hz}$ stimulus was inserted in the anterior posterior direction until contraction of one arm or forearm muscle or hand flexion (medial $n$.) or extension (radial n.) as response to brachial plexus stimuli was obtained. In general, needle penetration may vary from 2.5 to $4 \mathrm{~cm}$, according to patients physical constitution. When a good contraction was obtained, stimulator's current was readjusted to lower values. If there were still responses to stimuli below $0.5 \mathrm{~mA}$, certainly the blunt needle tip would be very close to the brachial plexus and the solution was injected. After negative blood aspiration, recently prepared $50 \mathrm{ml}$ of $1.6 \%$ lidocaine with epinephrine 1:200,000 were injected.

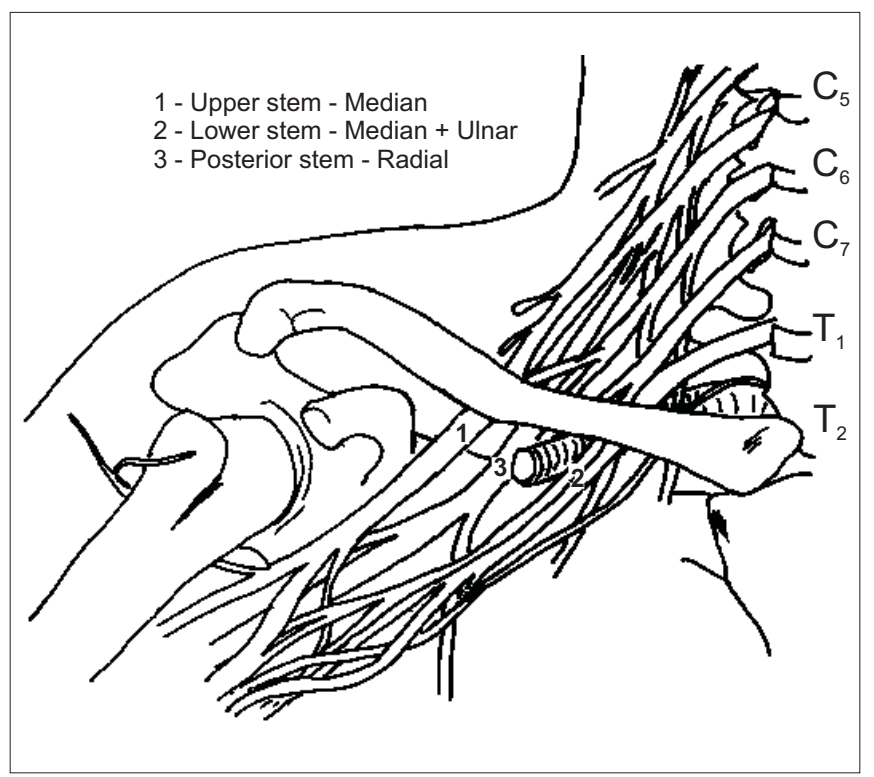

Figure 1 - Puncture Site

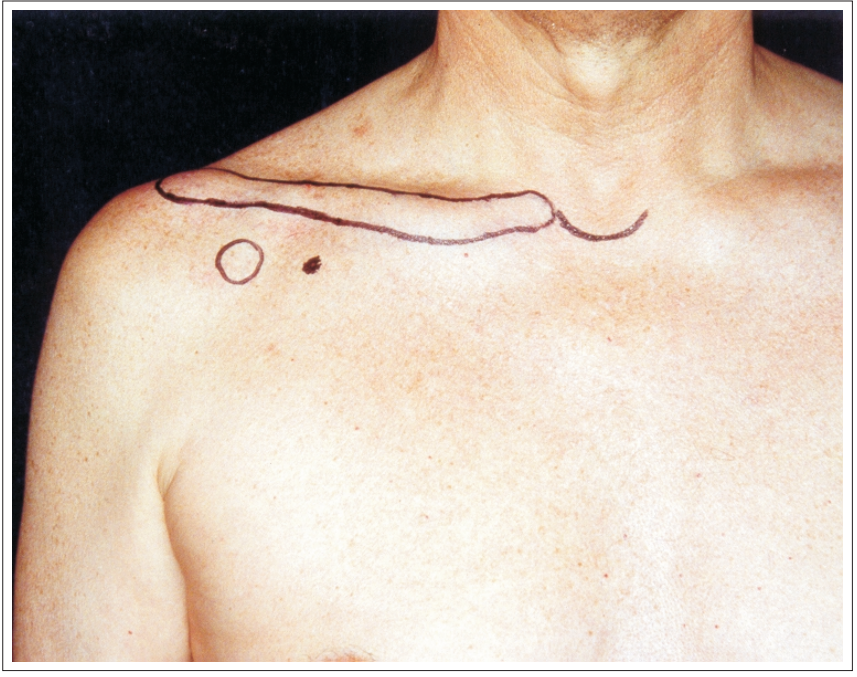

Figure 2 - Puncture Site

Anesthesia was evaluated by testing with a surgical forceps the sensory block extension for radial, median and ulnar nerves. The following parameters were evaluated: 1) anesthesia onset time - time between end of anesthetic injection and loss of sensitivity of the 3 nerves; 2 ) surgery duration - time between anesthetic injection and end of the procedure; 3 ) sensory block duration - time between anesthetic injection and total sensitivity recovery; 4) motor block duration - time between anesthetic injection and total limb movement recovery; 5) tourniquet perception; and 6) complications and side-effects. In case of partial or total failure, the protocol allowed for an interscalenic injection of half the planned dose. Some patients received $20 \mathrm{ml}$ of Omnipaque contrast $\left(300 \mathrm{mg} \mathrm{ml}^{-1}\right.$ ) associated to the anesthetic drug to study the spread of the injected volume at 1 minute and 60 minutes (Figures 3 and 4).

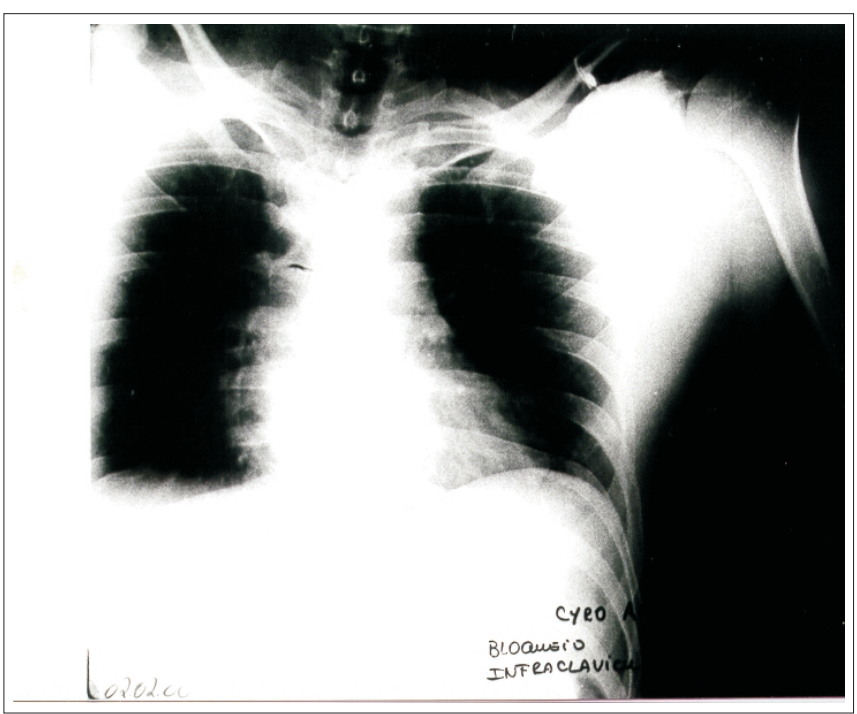

Figure 3 - Contrast Spread Together with Local Anesthetics

Revista Brasileira de Anestesiologia Vol. 51, № 3, Maio - Junho, 2001 


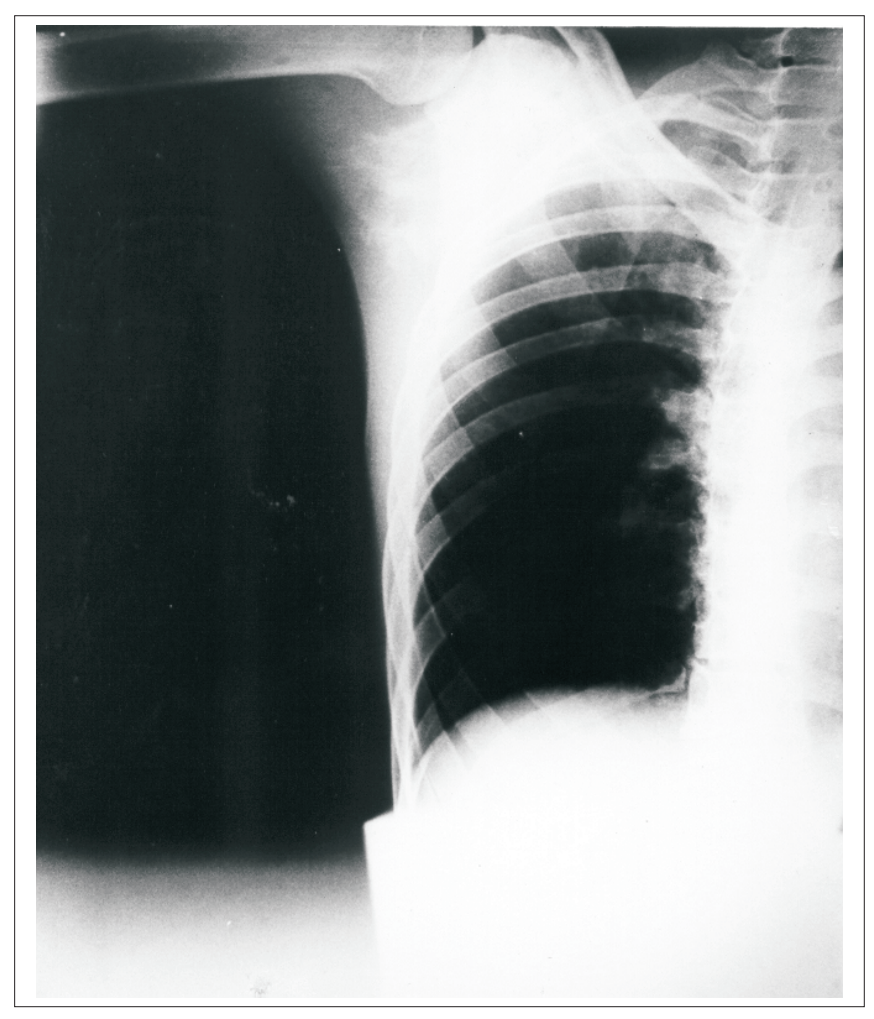

Figure 4 - Contrast 60 Minutes After Injection

At the end of the surgery patients were transferred to their rooms and in case of pain intravenous meperidine $30 \mathrm{mg}$ with metamizol $300 \mathrm{mg}$ were administered. Patients were followed up for 48 hours to check complications at blockade site and the success of the technique.

Results were evaluated by descriptive analysis of studied variables and, when possible, by mean and standard deviation.

\section{RESULTS}

Demographic data is shown in table I. Analgesia was adequate in 47 patients ( $94 \%$ ), partial in 2 patients $(4 \%)$ and failed in 1 patient $(2 \%)$. The ulnar nerve was blocked in all patients, with radial nerve failure in 1 patient and median nerve failure in 2 patients. Tourniquet tolerance was of $100 \%$ (used in 46 patients). Technique was considered satisfactory by 48 patients $(96 \%)$ and the 2 patients who received a second puncture for interscalenic block were not satisfied with the technique. There has been one vascular puncture before anesthetic injection. Needle was repositioned and blockade was performed without intercurrences.

Table I - Demographics Data

\begin{tabular}{lc}
\hline Age $\left(\right.$ years ${ }^{*}$ & $41.40 \pm 18.02$ \\
Weight $(\mathrm{kg})^{*}$ & $69.98 \pm 12.84$ \\
Height $(\mathrm{cm})^{*}$ & $167.98 \pm 09.29$ \\
Gender & \\
$\quad$ Male & 28 \\
$\quad$ Female & 22 \\
\hline
\end{tabular}

* Values are expressed as the Mean \pm SD

Revista Brasileira de Anestesiologia

Vol. 51, No 3, Maio - Junho, 2001
Surgery was performed in the arm of 7 patients and 4 did not need tourniquet.

Analgesia onset time was of 8.78 min and surgery duration of $65.52 \mathrm{~min}$. Sensory recovery elapsed time was of $195 \mathrm{~min}$ and motor block recovery time was of $198 \mathrm{~min}$ (Table II).

Table II - Blockade Effects

\begin{tabular}{lc}
\hline $\begin{array}{l}\text { Blocked nerves } \\
\text { Radial }\end{array}$ & $48(96 \%)$ \\
Medial & $48(96 \%)$ \\
Ulnar & $50(100 \%)$ \\
Analgesia & \\
Adequate & $47(94 \%)$ \\
Partial & $02(04 \%)$ \\
Failure & $01(02 \%)$ \\
Tourniquet tolerance & \\
Use in 44 patients & $44(100 \%)$ \\
02 patients + interscalenic & $02(100 \%)$ \\
04 patients without tourniquet & \\
Onset time (min) & $8.78 \pm 3.22\left(^{*}\right)$ \\
Analgesia duration (min) & $195.56 \pm 37.23\left(^{*}\right)$ \\
Motor block duration (min) & $198.86 \pm 37.56\left(^{*}\right)$ \\
Satisfaction with the technique & $48(96 \%)$ \\
\hline
\end{tabular}

$\left({ }^{*}\right)$ Values are expressed as the Mean $\pm \mathrm{SD}$

The contrast spread study performed in two patients showed that the mixture distributed chiefly in the infraclavicular space (Figure 2) and that after 60 minutes it could be detected in the axillary region (Figure 3 ).

No patient had clinical signs (apnea and cyanosis) of unilateral diaphragm paralysis secondary to phrenic nerve blockade. No complication was observed on puncture site.

\section{DISCUSSION}

The infraclavicular brachial plexus block technique provides a consistent, replicable and effective upper limb anesthesia. We believe that the major reason for its success is the deposition of the local anesthetics in the lateral, posterior and inferior brachial plexus branches by an adequate plexus location via neurostimulation. Infraclavicular block effectiveness $(94 \%)$ is comparable to axillary, supraclavicular and interscalenic access results ${ }^{1,15-17}$.

In general, brachial plexus access route depends on the surgery site. The axillary approach is adequate for hand surgery while infraclavicular, supraclavicular and interscalenic approaches are recommended for more proximal lesions. Anesthesia in the proximal upper limb (arm) has shown to be effective due to tourniquet tolerance in all patients, as well as in $14 \%$ of patients submitted to arm surgery. This also implies a blockade of axillary nerves and part of the intercostobrachial nerve. 
Labat described the infraclavicular approach in 1930, with a medial, posterior and cephalic access ${ }^{18}$, as from an infraclavicular point in the middle of the clavicle length, aiming at the Chassaignac tubercle. In 1973, it has been re-evaluated by Raj, who used an opposite approach to protect patients against a potential risk for pneumothorax ${ }^{11}$. Other authors proposed an access directed to the superior border of the second rib from an infraclavicular point just below the union of the lateral third with the two medial thirds of the clavicle, which also, in our opinion, seems to favor the incidence of pneumothorax 12. In our anterior posterior approach, the needle is inserted parallel to the costal grid and reduces the risk for pneumothorax. In addition, it makes the access easier by reducing the distance between the needle entry point and the brachial plexus (Figure 4).

Whenever a brachial plexus block is performed, there is a constant concern with the volume to be injected. The possible relation between the anesthetic volume injected and the extension of analgesia was firstly described in $1961^{19}$. Volumes between 40 and $55 \mathrm{ml}$ are associated to a higher rate of successful brachial plexus block, regardless of the access route ${ }^{15}$. In the infraclavicular approach, $50 \mathrm{ml}$ of $1.6 \%$ lidocaine with epinephrine 1:200,000 were responsible for a successful block in $94 \%$ of patients. Analgesia distribution partially depends on the volume. Diluted solutions and higher volumes favor blockade extension both cranially and distally, even allowing for shoulder surgeries.

The use of a nerve stimulator for nervous block was firstly reported in $1912^{20}$, but was soon abandoned for being too rudimental. Afterwards, it was reintroduced by Greenblatt and Denson ${ }^{21}$. Among several stimulator suppliers, we decided for the most accurate one ${ }^{22}$. The stimulator must generate a square wave stimulus, with a precision of a hundredth and preferably stimulating motor fibers, offering as response a muscle contraction before a painful response. In this study, after inserting the needle and obtaining a muscle response, the stimulator's output current was decreased to values close to $0.5 \mathrm{~mA}$. The presence of an even weak muscle response would indicate the correct needle positioning. After negative aspiration, the volume calculated for the patient was then slowly injected with a $10 \mathrm{ml}$ syringe while, by intermittent aspiration, the possibility of a vascular location of the needle and clinical signs of absorption were observed. The electrically insulated needle is important for the output current to be directed to the needle tip, allowing to work with lower currents 23,24 and a correct location close to the nerve, which may not occur with the conventional needle which, in addition to requiring higher currents, may confuse us about the location due to muscle contractions caused by a current leak along the needle to the muscles being crossed. The stimulator for brachial plexus location (or any other nervous complex) has the advantage of causing a muscle contraction while approaching a nerve (response to electrical stimulation) with no need for a painful mechanical stimulation (paresthesia), which may cause neuritis. The information is reliable and positive results reach $97 \%{ }^{17}$.
Different from other authors ${ }^{17}$, we performed the blockade with the help of a nerve stimulator without sedation or analgesia and patients remained awaken until the complete blockade of the three nerves. This must have been the reason for unsatisfaction in the two patients who needed supplementation with interscalenic block due to infraclavicular block partial or total failure.

Some authors advocate the use of multiple injections due to the presence of several compartments in the neurovascular sheath ${ }^{25}$. Infraclavicular local anesthetic injection was performed with a single injection and it was shown that, due to the effectiveness of the blockade, multiple injections are not needed in this technique.

The major supraclavicular and infraclavicular access complication is pneumothorax with incidence ranging from $0.5 \%$ to $6 \%{ }^{26}$. Although potentially dangerous, its incidence is extremely low when the technique follows a strict protocol. The absence of pneumothorax in more than 700 cases $^{27}$, shows that using the second rib as a guide, pleura remains more than 5 $\mathrm{cm}$ deep as compared to needle insertion point. No pneumothorax was observed in this small number of patients. The absence of toxic reactions during and after injection and the absence of respiratory depression show the safety of this brachial plexus access technique. Similarly and using the same volume and concentration of lidocaine in axillary brachial plexus block ${ }^{1}$, no toxic reaction was observed.

In the interscalenic brachial plexus approach, phrenic nerve and diaphragm paralysis can occur up to $100 \%$ of cases when 40-50 $\mathrm{ml}$ are injected ${ }^{28,29}$. A lower volume decrease and digital pressure applied close to the injection site do not prevent such complications ${ }^{30}$. With the infraclavicular block, phrenic nerve and diaphragm paralysis is impossible and there are no changes in respiratory function ${ }^{13}$. No phrenic nerve blockade was seen in our study. All patients received oxygen and maintained spontaneous ventilation without complaints, with or without sedation. Although the axillary artery, together with its veins, is part of the vascular-nervous bundle, we did not have any hematoma or intravascular injection. No patient had signs or symptoms of local anesthetic intoxication. No patient had Claude Bernard Horner syndrome.

In conclusion, the high degree of success and the absence of complications with the nerve stimulator used for brachial plexus infraclavicular access show that this is a safe, effective and easy technique.

\section{REFERÊNCIAS - REFERENCES}

01. Imbelloni LE, Pinto AL, Neumann CR - Bloqueio do plexo braquial pela via transarterial com altas doses de lidocaína 1,6\%. Rev Bras Anestesiol, 1989;39:273-276.

02. Stan TC, Krantz MA, Solomon DL et al - The incidence of neurovascular complications following axillary brachial plexus block using a transarterial approach. A prospective study of 1.000 consecutive patients. Reg Anesth, 1995;20:486-492.

03. Brown DL, Cahill DR, Bridenbaugh DL - Supraclavicular nerve block: anatomic analysis of a method to prevent pneumothorax. Anesth Analg, 1993;76:530-534.. 
04. Winnie AP, Collins VJ - The subclavian perivascular technique of brachial plexus anesthesia. Anesthesiology, 1964;25:353-363.

05. Vieira JL - Bloqueio do plexo braquial. Rev Bras Anestesiol, 1995;45(Sup 20):106-115.

06. Urmey WF - Brachial plexus block. Curr Opin Anesthesiol, 1992;5:666-671.

07. Winnie AP - Interescalene brachial plexus block. Anesth Analg, 1970;49:455-466.

08. Moore DC - "No paresthesias - no anesthesia", the nerve stimulator or neither? Reg Anesth, 1997;22:388-390.

09. Selander D, Edshage S, Wolff T - Paresthesiae or no paresthesiae? Acta Anaesthesiol Scand, 1979;3:27-33.

10. Raj PP - Guidelines for Regional Anesthetic Techniques, em: Hahn MB, McQuillan PM, Sheplock GJ - Regional Anesthesia: An Atlas of Anatomy and Techniques. Mosby-Year Book, Inc 1996;21-38.

11. Raj PP, Montgomery SJ, Nettles D et al - Infraclavicular brachial plexus block. Anew approach. Anesth Analg, 1973;52:897-904.

12. Salazar CH, Espinosa W - Infraclavicular brachial plexus block: variation in approach and results in 360 cases. Reg Anesth Pain Med, 1999:24:411-416.

13. Rodríguez J, Bárcena M, Rodríguez V et al - Infraclavicular brachial plexus block effects on respiratory function and extent of the block. Reg Anesth Pain Med, 1998;23:564-568.

14. Fitzgibbon DR, Debs AD, Erjavec MK - Selective musculocutaneus nerve block and infraclavicular brachial plexus anesthesia. Case Report. Reg Anesth, 1995;20:239-241.

15. Geier KO - Bloqueio do plexo braquial no trauma: analgesia regional prolongada por cateter axilar. Rev Bras Anestesiol, 1995;45:173-182.

16. Urban MK, Urquhart B - Evaluation of bachial plexus anesthesia for upper extremity surgery. Reg Anesth, 1994;19:175-182.

17. Franco CD, Vieira ZE - 1.001 subclavian perivascular brachial plexus blocks: success with a nerve stimulator. Reg Anesth Pain Med, 2000;25:41-46.

18. Labat G - Regional Anesthesia. Philadelphia, WB Saunders, 1930.

19. De Jong RD - Axillary block of the brachial plexus. Anesthesiology, 1961;26:215-225.

20. Perthes G - Conduction anesthesia with the help of electrical stimulation. München Med Wochenschr, 1912;59:2545-2548.

21. Greenblatt GM, Denson JS - Needle nerve stimulator-locator. Nerve blocks with a new instrument for locating nerves. Anesth Analg, 1962;41:599-602.

22. Barthram $\mathrm{CN}$ - Nerve stimulators for nerve location - Are they all the same? A study of stimulator performance. Anaesthesia, 1997; 52:761-764

23. Ford DJ, Pither C, Raj PP - Comparison of insulated and uninsulated needles for locating peripheral nerves with a peripheral nerve stimulator. Anesth Analg, 1984;63:925-928.

24. Bashein G, Haschke RH, Ready LB - Electrical nerve location: numerical and electrophoretic comparison of insulated vs uninsulated needles. Anesth Analg, 1984;63:919-24.

25. Thompson GE, Rorie DE - Functional anatomy of brachial plexus sheaths. Anesthesiology, 1983;59:117-122

26. Moore DC - Complications of regional anesthesia. Clin Anesth, 1969;2:218-251.

27. Salazar CH, Espinosa W - Bloqueo Infraclavicular del Plexo Braquial, em: Aliaga L, Castro MA, Català E et al - Anestesia Regional Hoy. Barcelona, Publicationes Permanyer, 1998;249-257.
28. Urmey WF, Talts KH, Sharrock EN - One hundred percent incidence of hemidiaphragmatic paresis associated with interescalene brachial plexus anesthesia as diagnosed by ultrasonography. Anesth Analg, 1991;72:498-503.

29. Sala-Blanch X, Lázaro JF, Gómez-Fernández M et al - Parális frénica tras bloqueo del plexo braquial. Estudio comparativo entre el abordaje interescalénica y el axilar. Rev Soc Esp Dolor, 1997:4:238-244.

30. Sala-Blanch X, Lázaro JF, Correa J et al - Phrenic nerve block caused by interscalene brachial plexus block: effects of digital pressure and a low volume of local anesthetic. Reg Anesth Pain Med, 1999;24:231-235.

\section{RESUMEN}

Imbelloni LE, Beato L, Gouveia MA - Bloqueo del Plexo Braquial por Vía Infraclavicular: Abordaje Antero-Posterior

Justificativa y Objetivos - El bloqueo del plexo braquial es la técnica preferida por los anestesistas para cirugías en los miembros superiores. Aun cuando el acceso infraclavicular sea menos utilizado, él puede ofrecer algunas ventajas. El objetivo de este estudio prospectivo es mostrar los resultados observados en 50 pacientes sometidos a bloqueo del plexo braquial por la vía infraclavicular, usando estimulador del nervio periférico y abordaje antero-posterior.

Método - Cincuenta pacientes, con edades entre 17 y 87 años, estado físico ASA I y II, escalados para cirugías ortopédicas de la extremidad superior fueron anestesiados con bloqueo del plexo braquial por la vía infraclavicular. Todos los bloqueos fueron realizados con estimulador de nervio periférico, a partir de $1 \mathrm{~mA}$. Cuando se obtenía una adecuada contracción muscular en la mano, en el antebrazo o músculos del brazo, el amperaje era disminuido hasta el desaparecimiento de la respuesta. Si la respuesta desapareciese con estímulo superior a 0,6 mA, la aguja podría ser movimentada en la búsqueda de la mejor respuesta. Si la respuesta no desapareciese con estímulo menor que $0,5 \mathrm{~mA}$, se inyectaban $50 \mathrm{ml}$ de lidocaína a $1,6 \%$ con epinefrina 1:200.000. Fueron evaluados el tiempo de latencia, duración de la cirugía, tolerancia al uso del torniquete, duración de los bloqueos sensitivo y motor, complicaciones y efectos adversos.

Resultados - El bloqueo fue efectivo en $94 \%$ de los pacientes, el tiempo medio de la latencia fue de $8,78 \mathrm{~min}$, la duración media de la cirugía fue de $65,52 \mathrm{~min}$ y la tolerancia al torniquete fue observada en todos los pacientes. La media de duración del bloqueo sensitivo fue de 195,56 min y del bloqueo motor de 198,86 min. Ocurrió una punción vascular. No fueron observados señales y síntomas clínicos de toxicidad del anestésico local o del vasoconstrictor. Ningún paciente presentó efectos adversos del bloqueo.

Conclusiones - El bloqueo infraclavicular del plexo braquial proporciona una efectiva anestesia para cirugías de los miembros superiores. Acreditamos que la técnica que utiliza el estimulador de nervios periférico proporciona un alto índice de suceso y demostró que es segura. No fue observado ningún caso de pneumotórax o cualquier otro tipo de complicación. La solución del anestésico utilizada proporcionó una anestesia segura y adecuada. 